\title{
ANALYSIS OF TWO ADJACENT TUNNELS IN SOFT CLAY SOIL*
}

EIJEST

\section{ABSTRACT}

Gouda A. M. Attia, Eman A. M. Elshamey, Hesham M. Fawzy, Khaled Abdul-hafez**

Structural Engineering, Zagazig University, Egypt.

The design of tunnel cross section depends on the values of internal forces and deformations induced in the lining. These values are influenced by many factors such as type of soil, method of construction and dimensions of the tunnel cross section. In the present study, a numerical analysis is proposed using finite element software Adina version 8.5 (A finite element code for soil and rock analyses). A numerical model is presented as a plane strain problem with two dimensions element of specific-node to present the soil elements and specific -node beam element to simulate the lining of the circular, elliptical, and horse shoe tunnel. The material of the lining was chosen as a reinforced concrete beam. The properties of the selected soil are as constant properties with an elastic linear model involve two elastic stiffness parameters: Young's modulus $\left(\mathrm{E}_{\mathrm{s}}\right)$ and Poisson's ratio $(v)$. With this numerical model, the horizontal and vertical boundary dimensions, as well as the interaction between the two tunnels parallel twins, according to the distance between the central lines of the tunnel; was also study the effect of the change in stiffness of soft clay soils using the three values of the modulus of elasticity $\left(\mathrm{E}_{\mathrm{s}}\right)$ and the Poisson ratio $(v)$. The effect of the thickness- radius ratio ( $\left.\mathrm{t} / \mathrm{r}\right)$ on the displacement tunnel under the ground surface at a depth 6 times the radius of the tunnel from the surface of the ground until the center of the tunnel, also obtained the best shape tunnel in soft clay soil with different values for $\left(\mathrm{E}_{\mathrm{s}}\right)$ and $(v)$.Effect of three types of soft clay soil on the values of internal forces and displacement induced in lining has been determined. These types depend on values of $\left(E_{s}\right)$ and $(v)$. Comparisons between the values of the bending moments as well as the settlement induced at the horizontal line of the tunnel cross section with the maximum values have been determined. Design charts for the bending moments as well as settlement to predict the maximum bending moments as well as the maximum normal forces induced in the lining have been introduced.

KEY WORDS: circular tunnel, elliptical tunnel, horseshoe tunnel, Finite Element.

ANALYSE DES DEUX ADJACENT TUNNELS DANS UN SOL ARGILEUX SOFT

\section{RÉSUMÉ}

La conception de la section transversale du tunnel est fonction des valeurs des forces internes et des déformations induites dans la doublure. Ces valeurs sont influencées par de nombreux facteurs tels que le type de sol, la méthode de construction et les dimensions de la section du tunnel. Dans la présente étude, une analyse numérique est proposé d'utiliser le logiciel d'éléments finis Adina version 8.5 (Un code d'éléments finis pour analyses de sols et de roches). Un modèle numérique est présenté comme un problème de déformation plane avec deux dimensions de l'élément spécifique nœud de présenter les éléments du sol et de l'élément faisceau spécifique nœuds pour simuler la muqueuse de la circulaire, elliptique, et le tunnel de fer à cheval. Le matériau de la garniture a été choisie comme une poutre en béton armé. Les propriétés du sol sélectionné sont les propriétés constantes avec un modèle élastique linéaire intervenir deux paramètres de rigidité élastiques: module de Young (Es) et le coefficient de Poisson (v). Avec ce modèle numérique, les dimensions limites horizontales et verticales, ainsi que l'interaction entre les deux jumeaux de deux tunnels parallèles, en fonction de la distance entre les lignes centrales du tunnel; est également étudier l'effet de la variation de la rigidité des sols argileux mous en utilisant les trois valeurs du module d'élasticité (ES) et le coefficient de Poisson (v). L'effet du rapport épaisseur de rayon $(\mathrm{t} / \mathrm{r})$ sur le tunnel de déplacement sous la surface du sol à une profondeur 6 fois le rayon du tunnel à partir de la surface du sol jusqu'à ce que le centre du tunnel, le tunnel a également obtenu le meilleur forme dans un sol argileux doux avec des valeurs différentes pour (Es) et ( $v$ ). Effet de trois types de sols d'argile molle sur les valeurs de forces internes et des déplacements induits dans la doublure a été déterminée. Ces types dépendent de la valeur de (s) et (v). Des comparaisons entre les valeurs des moments de flexion ainsi que le règlement induite au niveau de la ligne horizontale de la section du tunnel avec des valeurs maximales ont été déterminées. Graphiques de conception pour les moments de flexion ainsi que le règlement afin de prévoir les moments de flexion maximaux ainsi que les forces maximales normales induites dans la doublure ont été introduites.

MOTS CLÉS: tunnel circulaire, elliptique tunnel, tunnel de fer à cheval, des éléments finis.

\footnotetext{
* Received: 18/3/2012, Accepted: 3/6/2012 (Original Paper)

** Contact author (+2 0115556 4412, engkh_moro@yahoo.com)
} 
ANALYSIS OF TWO ADJACENT TUNNELS IN SOFT CLAY SOIL

Attia, Elshamey, Fawzy, Abdul-hafez

\section{INTRODUCTION}

The analysis of tunnel cross section can be obtained by Laboratory experiments: by model tests, Field tests: by measuring the values of deformation and stresses directly in situ and numerical studies: by modeling the tunnel cross section and surrounding soil..Laboratory experiments: Abdel Salam, S.S. (1979) studied stress distribution around two adjacent equal elliptical tunnels. In this investigation an experimental technique of a two dimensional photoelastic models is used. Attia, G. (1991) performed a numerical and photo-elastic analysis of tunnels containing cracks. In this study, effect of crack location and crack depth were investigated for different loading conditions, soil properties and tunnel configurations. Field tests: M. Alba, et al (2010) introduced the development and testing of a method for tunnel monitoring via vision metrology. Tunnel monitoring is an important task in civil engineering that aims at determining the stability and safety of a structure by using information about its deformations. Saied Mohammad, et al (2012) introduced the relationship between twin tunnel distance and surface subsidence in soft ground. In this paper a series of three-dimensional finite distinct element analyses carried out for line 1 of Tabriz metro tunnels are presented. Numerical studies: Abo. Elanwar .M. (2006) performed an analysis of circular tunnels embedded in Soil the design of tunnel cross section depends on the values of internal forces and deformations induced in the lining. Chong Hun YEO, et al (2008) introduced the three dimensional numerical modeling of a NATM tunnel the design of NATM tunnels are often done in two dimensions, even though there are limitations. Kentaro Yamamoto, et al (2011) presented the stability of a circular tunnel in cohesive-frictional soil subjected to surcharge loading .

\section{DESCRIPTION OF MODELS}

In this paper, three model of adjacent tunnel are studied; circular, elliptical and horseshoe. The diameter reinforced concrete tunnel is $10 \mathrm{~m}$ with a modulus of elasticity $\left(E_{c}=2.1 * 10^{7} \mathrm{KN} / \mathrm{m}^{2}\right)$, $\mu_{c}=0.15$ and a thickness-radius ratio for the wall $(\mathrm{t} / \mathrm{r}=0.1,0.3$ and 0.5$)$ in anon-linear soft clay soil with parameters $\mathrm{Es}=500,1000$ and $1500 \mathrm{KN} / \mathrm{m}^{2}$ $\mu=0.39,0.45$ and 0.49 are in one layer of soil deposit of constant distance equal to (7R) from center line of the tunnels as shown in Fig. (1). Also shows the key plan of the tunnel results, (sl) is left spring point, (cr) is the crown point and (sr) is the right spring point of the tunnel with regard to the finite element solution.

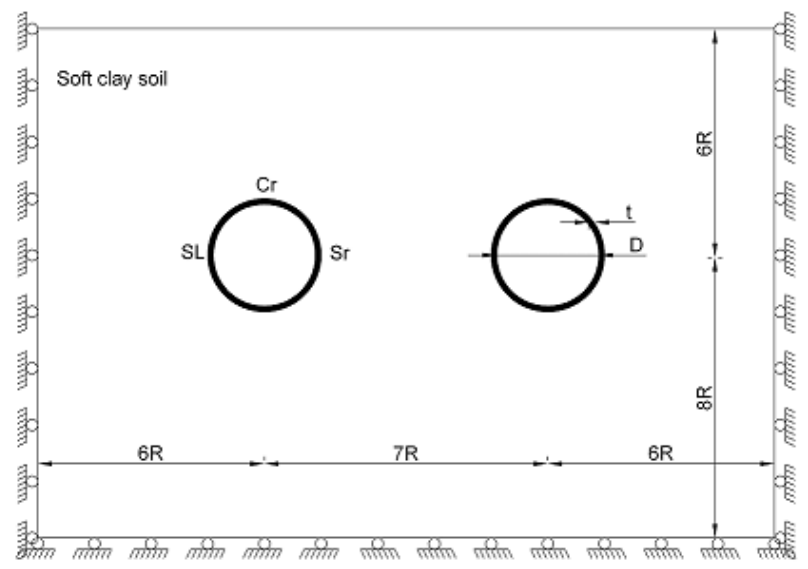

Fig (1): Layout of two adjacent circular tunnels

The geometry of idealized model has been represented by an appropriate mesh as shown in Fig (2), which displays the finite element; mesh of the soil around the tunnels is in symmetry.

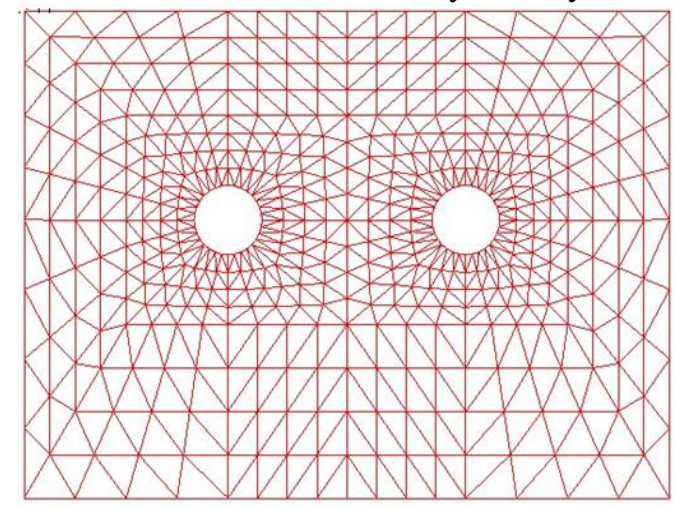

\section{Fig (2): Finite element mesh of two adjacent circular tunnels}

A typical section of the two elliptical tunnels. The diameter reinforced concrete tunnel is $(5 \mathrm{~m}, 10 \mathrm{~m})$ (A, B) which $\mathrm{B} / \mathrm{A}=2$ with a modulus of elasticity $\left(E_{c}=2.1 * 10^{7} \mathrm{KN} / \mathrm{m}^{2}\right), \mu_{c}=0.15$ and a wall $(\mathrm{t} / \mathrm{r}=0.1$, 0.3 and 0.5$)$ in anon-linear soft clay soil with parameters $\mathrm{E}=500,1000$ and $1500 \mathrm{KN} / \mathrm{m}^{2} \mu=0.39$, 0.45 and 0.49 are constructed in one layer of soil deposit of constant distance equal to (7R) from center line of the tunnels as shown in Fig. (3). Also 
shows the key plan of the tunnel results, (sl) is left spring point, (cr) is the crown point and (sr) is the right spring point of the tunnel with regard to the finite element solution.

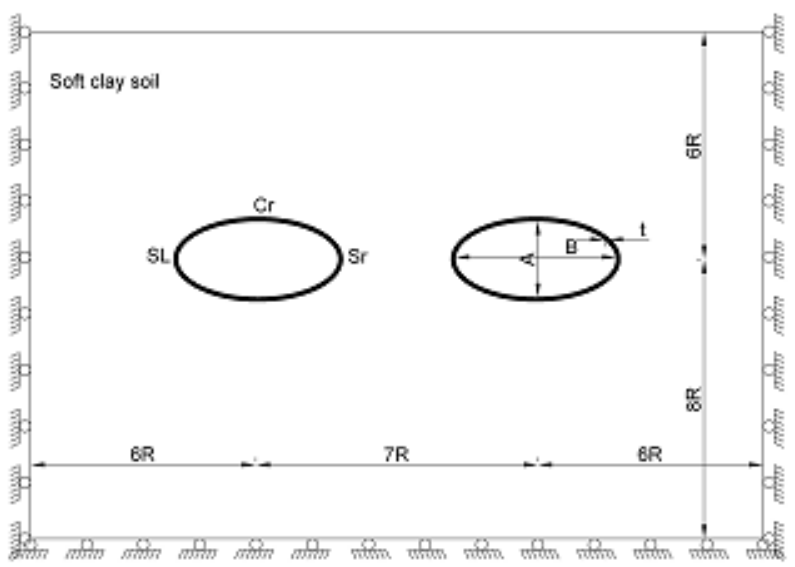

Fig (3): Layout of two adjacent elliptical tunnels

The geometry of idealized model has been represented by an appropriate mesh as shown in Fig (4), which displays the finite element; mesh of the soil around the tunnels is in symmetry.

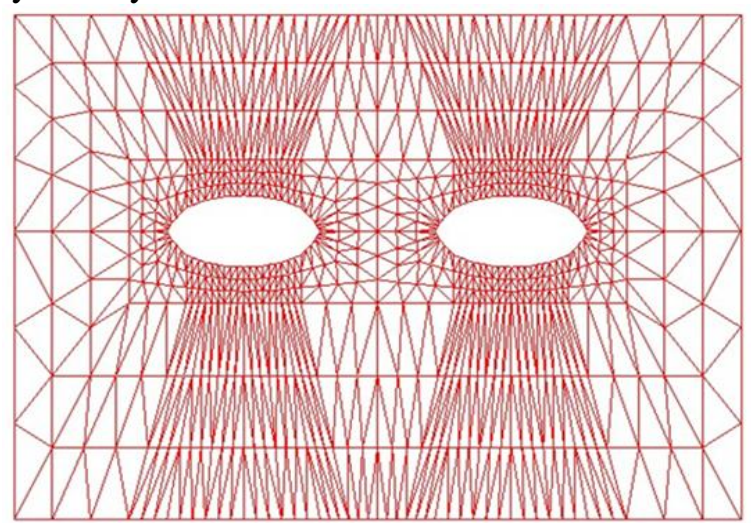

Fig (4): Finite element mesh of two adjacent elliptical tunnels

A typical section of the two horse show tunnels. The diameter reinforced concrete tunnel is $10 \mathrm{~m}$ with a modulus of elasticity $\left(E_{c}=2.1 * 10^{7} \mathrm{KN} / \mathrm{m}^{2}\right)$, $\mu_{c}=0.15$ and a wall $(\mathrm{t} / \mathrm{r}=0.1,0.3$ and 0.5$)$ in anonlinear soft clay soil with parameters $=500,1000$ and $1500 \mathrm{KN} / \mathrm{m}^{2} \mu=0.39,0.45$ and 0.49 are constructed in one layer of soil deposit of constant distance equal to (7R) from center line of the tunnels as shown in Fig (5). Also shows the key plan of the tunnel results.

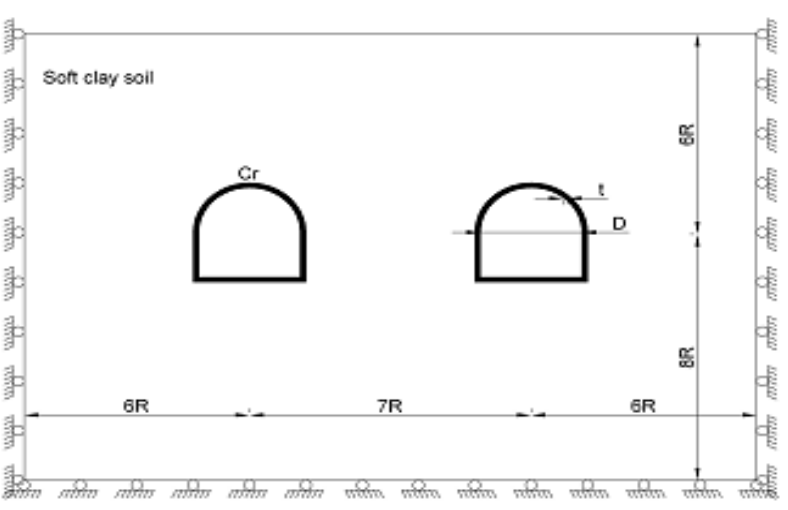

Fig (5): Layout of two adjacent horseshoe tunnels

The geometry of idealized model has been represented by an appropriate mesh as shown in Fig (6), which displays the finite element; mesh of the soil around the tunnels is in symmetry.

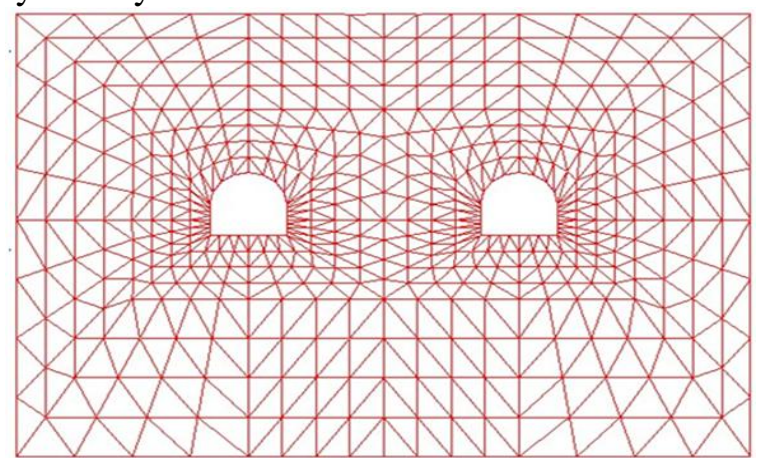

Fig (6): Finite element mesh of two adjacent horseshoe tunnels

\section{CASE OF THE MODEL LOADING}

In this study three cases of loading which the load $(\mathrm{p}=100 \mathrm{KN} / \mathrm{m})$ as shown as Fig (7), Fig (8), Fig (9).

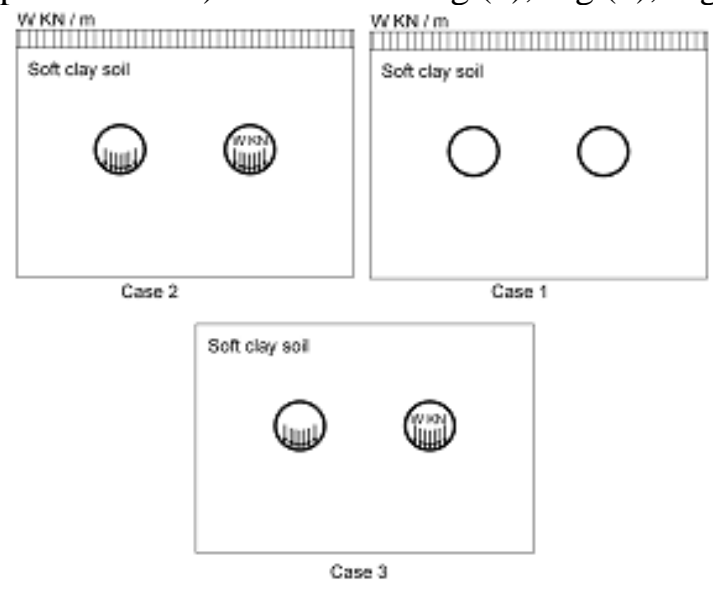

Fig (7): Case of the circular tunnel loading 


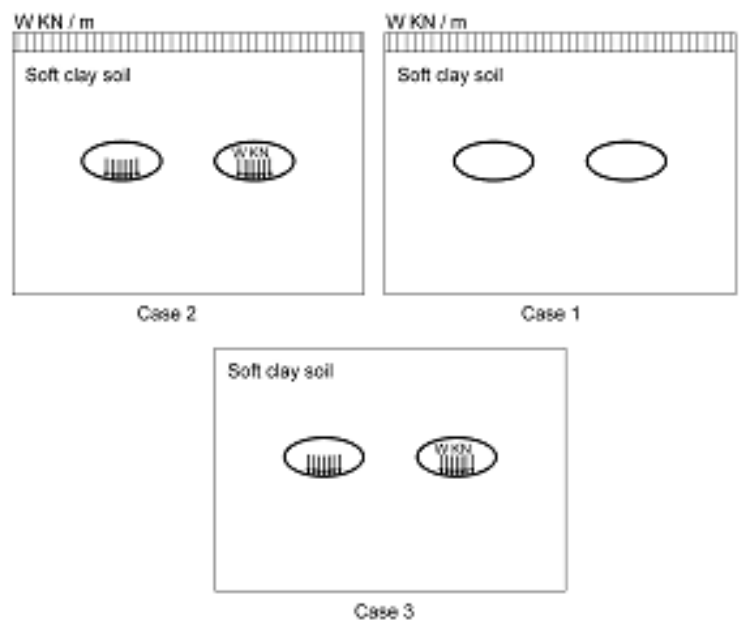

Fig (8): Case of the elliptical tunnel loading.

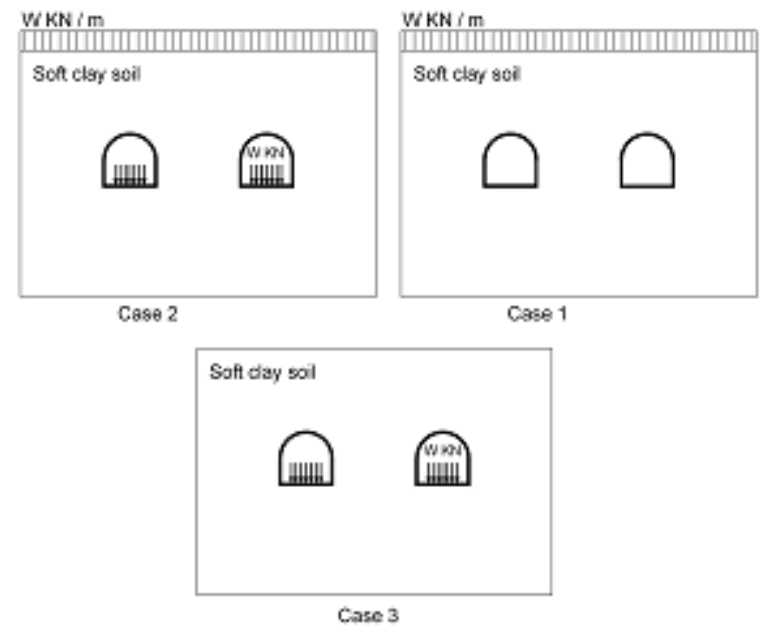

Fig (9): Case of the horse shoe tunnel loading

\section{PARAMETERS OF THE MODEL}

In this investigation, the finite element model had been used with known dimensions for the tunnel and soil boundaries. The depth value of tunnel and the soil which death and the tunnel birth instead of it had been kept constant during all the analyzed cases, where all the studied models are in the conditions. On the other hand, different shapes and diameters of tunnels and stiffness had been used in the present investigation, which external live Pressure $=100 \mathrm{KN} / \mathrm{m}^{2}$, internal live load $=100 \mathrm{KN}$, tunnel depth $(\mathrm{h})=6 \mathrm{R}, \mathrm{L}$ (distance between center line of tunnels) $=7 R$, Shape of tunnel circular, elliptical and horse shoe. Modulus of elasticity for tunnel $(\mathrm{Ec})=2.1 * 10^{7} \mathrm{KN} / \mathrm{m}^{2}$., diameter of tunnel $=10 \mathrm{~m}, \mathrm{t} / \mathrm{r}=0.1,0.3$ and $0.5 \quad \mathrm{Es}=500,1000$ and $1500 \mathrm{KN} / \mathrm{m}^{2} \cdot \mu=0.39,0.45$ and 0.49 .

\section{EFFECT THE TYPE OF SOIL}

In this analysis, the values of (Es, $\mu)$ is given in tables (1),(2). For each type of soil, we will study the effect of $(\mathrm{t} / \mathrm{r})$ on the vertical displacement at upper (cr) of three shape of tunnel (circular, elliptical and horse shoe) for three cases, $\mathrm{t} / \mathrm{r}=0.1,0.3$ and 0.5 and Comparisons between the values of displacement for each shape.

Table (1): $\mathrm{E}_{\mathrm{s}}$ for different soils.

\begin{tabular}{||l||l|l||}
\hline \hline Soil Type & Classification & $\mathrm{E}_{\mathrm{S}}\left(\mathrm{MN} / \mathrm{m}^{2}\right)$ \\
\hline \hline \multirow{4}{*}{ Clay } & Soft & $0.50-2.0$ \\
\cline { 2 - 3 } & Medium Stiff & $1.50-6.0$ \\
\cline { 2 - 3 } & Stiff & $2.50-10.0$ \\
\cline { 2 - 3 } & Very Stiff & $5.0-20.0$ \\
\cline { 2 - 3 } & Hard & $10.0-40.0$ \\
\hline \hline \multirow{4}{*}{ Silt } & & $3.0-30.0$ \\
\hline \hline \multirow{3}{*}{ Sand } & Loose & $10.0-25.0$ \\
\cline { 2 - 3 } & Medium Dense & $25.0-75.0$ \\
\cline { 2 - 3 } & Dense & $75.0-150.0$ \\
\cline { 2 - 3 } & Very Dense & $150.0-400.0$ \\
\hline \hline Gravel & & $100.0-400.0$ \\
\hline \hline Organic & & $0.50-2.0$ \\
\hline \hline
\end{tabular}

Table (2): $\mu$ s for different soils

\begin{tabular}{|l|c|}
\hline \multicolumn{1}{|c|}{ Soil type } & Poisson's ratio, $v$ \\
\hline Coarse sand & $0.15-0.20$ \\
Medium loose sand & $0.20-0.25$ \\
Fine sand & $0.25-0.30$ \\
Sandy silt and silt & $0.30-0.35$ \\
Saturated clay (undrained) & 0.50 \\
Saturated clay--lightly overconsolidated (drained) & $0.2-0.4$ \\
\hline
\end{tabular}

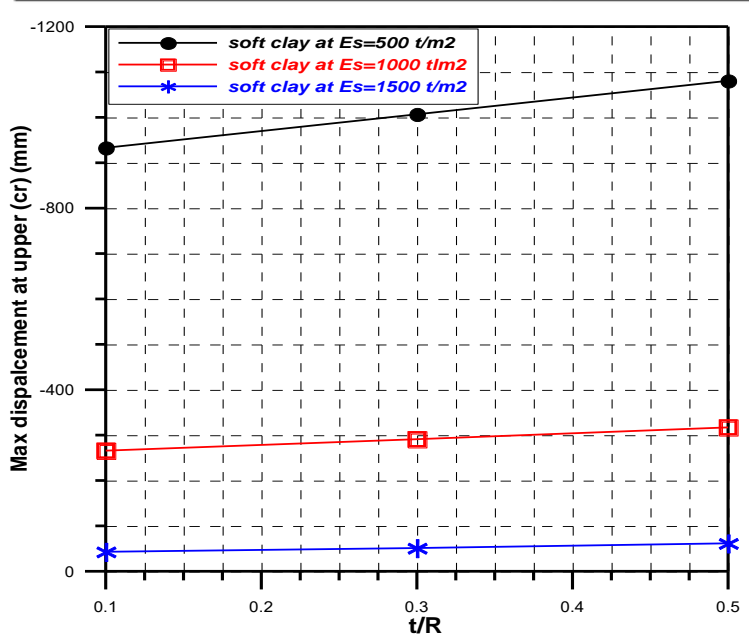

Fig (10): Effect of $(t / r)$ on the vertical displacement at upper (cr) of two adjacent circular tunnels, case1 


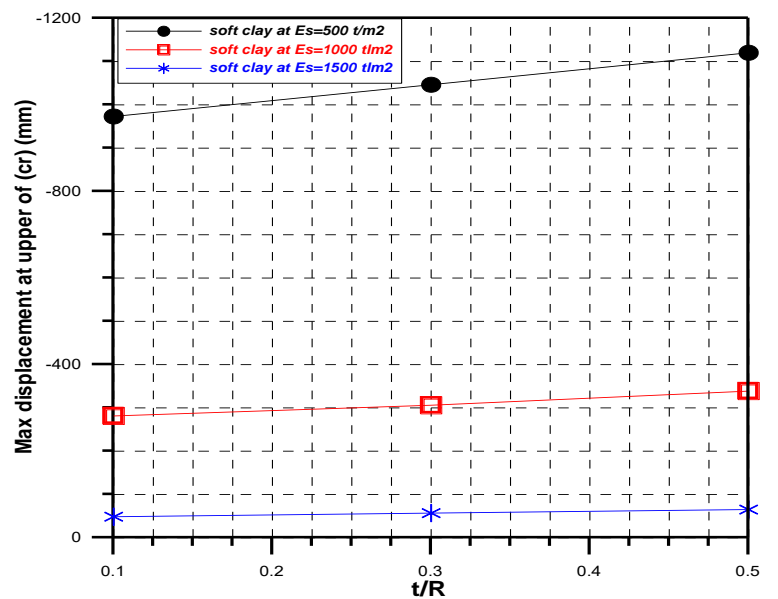

Fig (11): Effect of ( $t / r)$ on the vertical displacement at upper (cr) of two adjacent circular tunnels, case2.

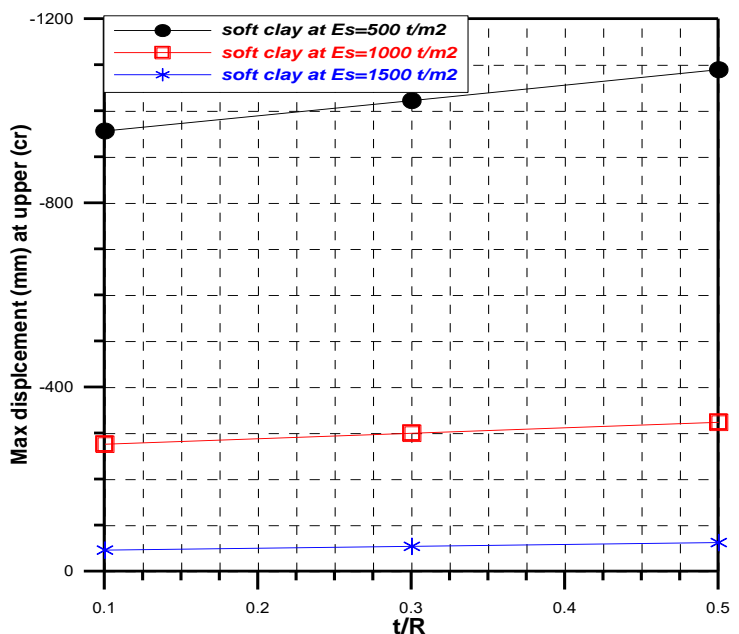

Fig (12): Effect of $(t / r)$ on the vertical displacement at upper (cr) of two adjacent circular tunnels, case3.

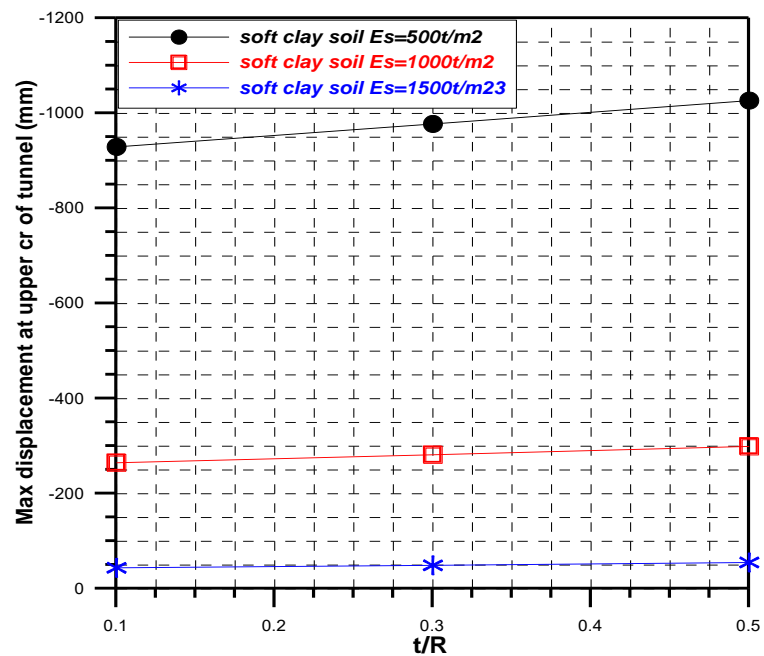

Fig (13): Effect of (t/r) on the vertical displacement at upper (cr) of two adjacent Elliptical tunnels, case1

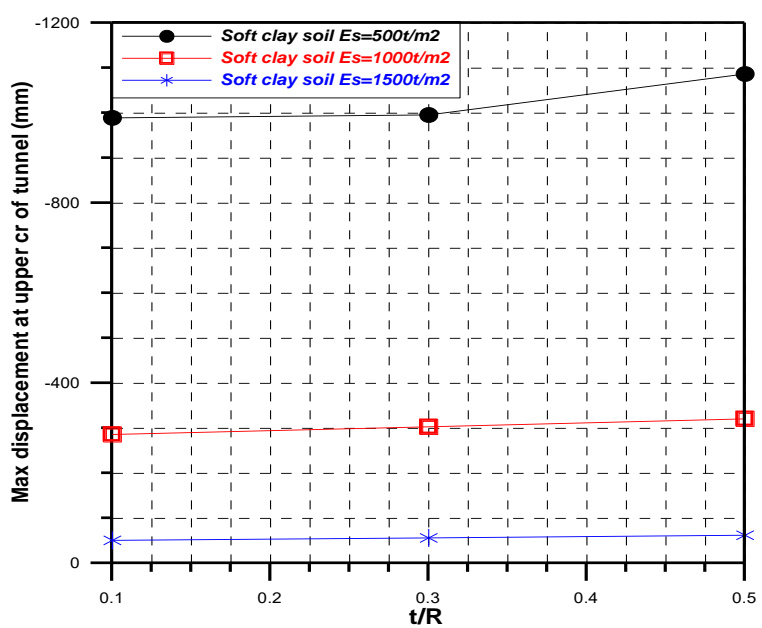

Fig (14): Effect of ( $t / r)$ on the vertical displacement at upper (cr) of two adjacent Elliptical tunnels, case2.

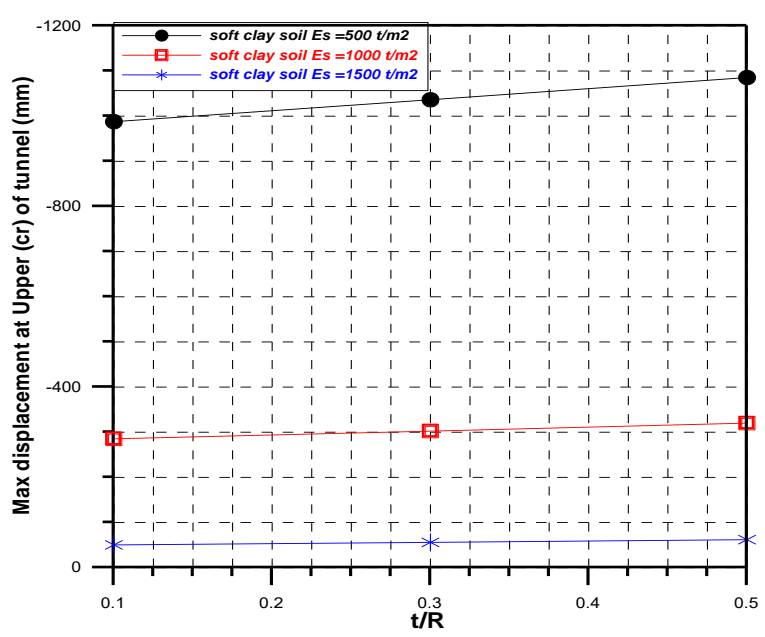

Fig (15): Effect of ( $t / \mathbf{r})$ on the vertical displacement at upper (cr) of two adjacent Elliptical tunnels, case3.

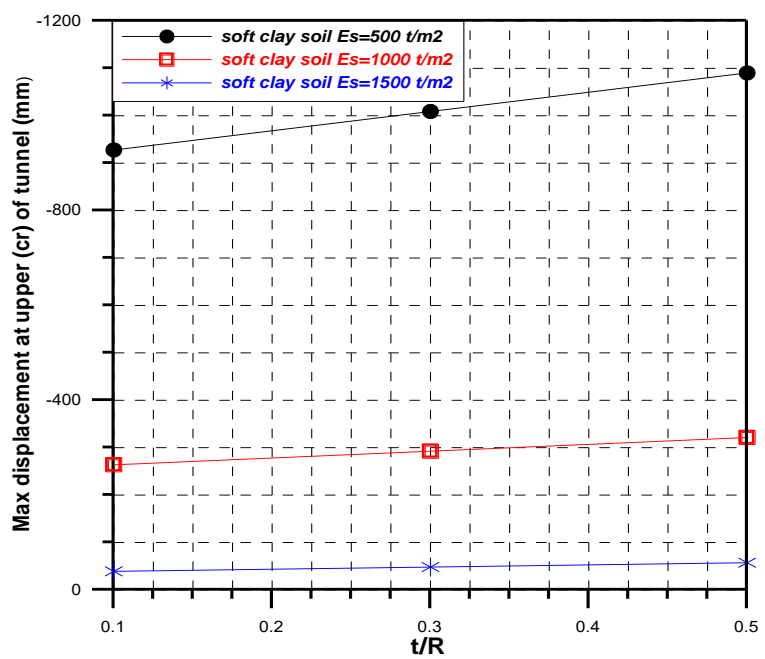

Fig (16): Effect of ( $t / \mathbf{r})$ on the vertical displacement at upper (cr) of two adjacent Horse shoe tunnels, case1. 
ANALYSIS OF TWO ADJACENT TUNNELS IN SOFT CLAY SOIL

Attia, Elshamey, Fawzy, Abdul-hafez

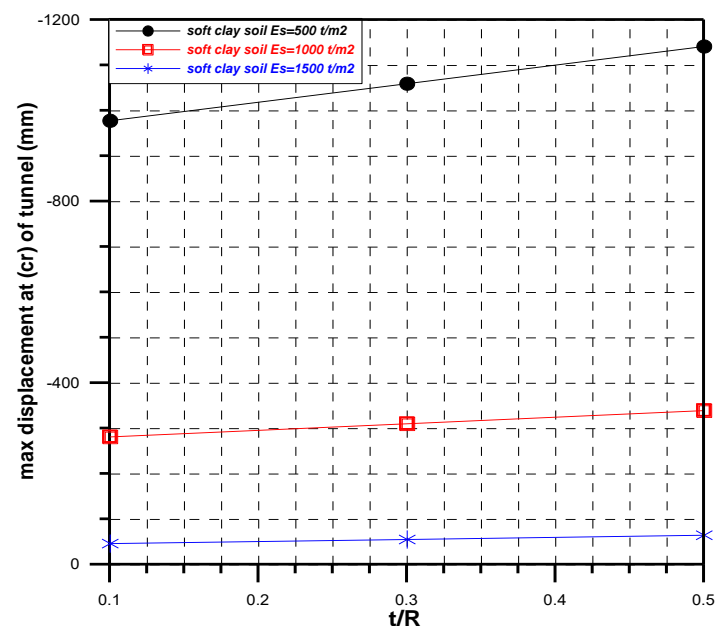

Fig (17): Effect of (t/r) on the vertical displacement at upper (cr) of two adjacent Horse shoe tunnels, case2.

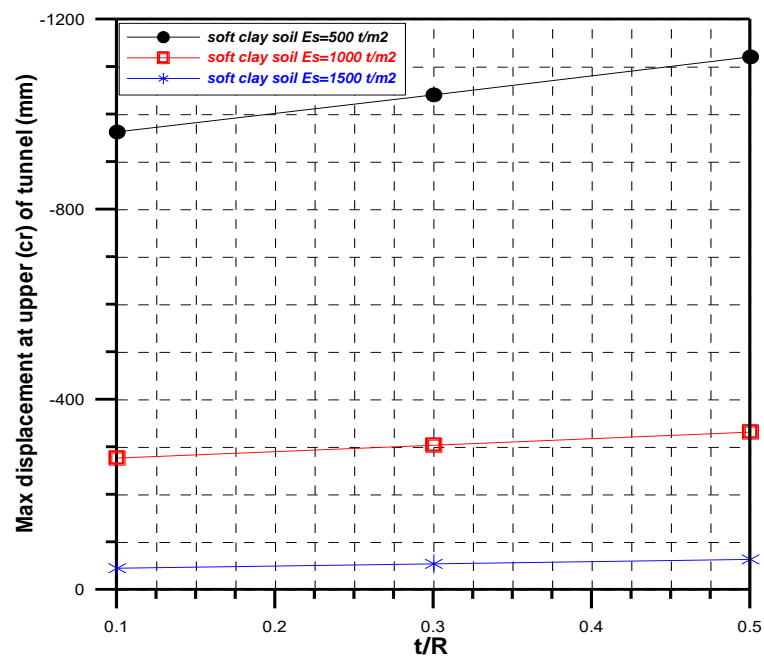

Fig (18): Effect of $(t / r)$ on the vertical displacement at upper (cr) of two adjacent Horse shoe tunnels, case3.

From fig (1 $\left.)^{\prime}\right)$ to fig $\left(1^{\wedge}\right)$ show the effect of $(t / r)$ on max displacement at upper (cr) of tunnel which increases at case 2 for all shapes of tunnel due to increases modulus elasticity of soft clay (Es) After many studies for the three shapes of tunnel it is observed that the displacement at upper (cr) when an elastic modulus of soil and Poisson ratio change from $($ Es, $\mu)=(500,0.39)$ to $($ Es, $\mu)=(1000,0.45)$. Decrease $70 \%$. the displacement at (cr) when an elastic modulus of soil and Poisson ratio change from $(E s, \mu)=(1000,0.45)$ to $(E s, \mu)=(1500,0.49)$ decease $80 \%$ for all shapes of tunnel and after Comparisons between the values of displacement for each shape it is observed the displacement elliptical tunnel at (cr) is less than the circular tunnel and horse shoe tunnel in soft clay.
In this investigation we will see the effect of type of soft clay soil at three cases, $(\mathrm{t} / \mathrm{r}=0.5)$ on maximum bending moment and normal force for lining of circular, elliptical and horse shoe tunnel and Comparisons between the values of internal force for each shape. In this paper we can use $\mathrm{M} 0=$ $79.364 \mathrm{t} / \mathrm{m} 2$.and $\mathrm{N} 0=213.960$ ton

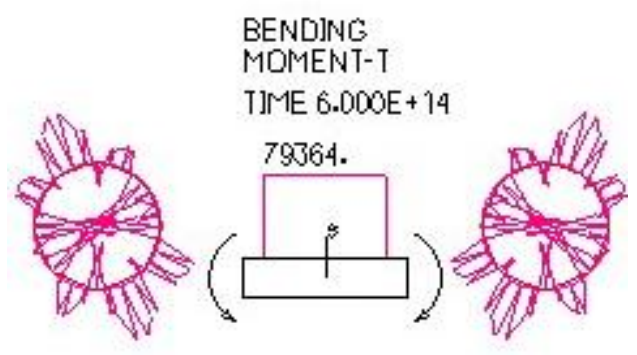

Fig (19): maximum BM of circular tunnel $(E s, \mu)=(500,0.39), t / r=0.5$, case 1

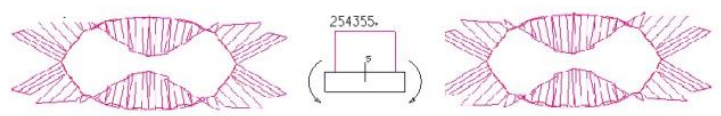

Fig (20): maximum BM of elliptical tunnel $($ Es, $\mu)=(500,0.39), t / r=0.5$, case 1

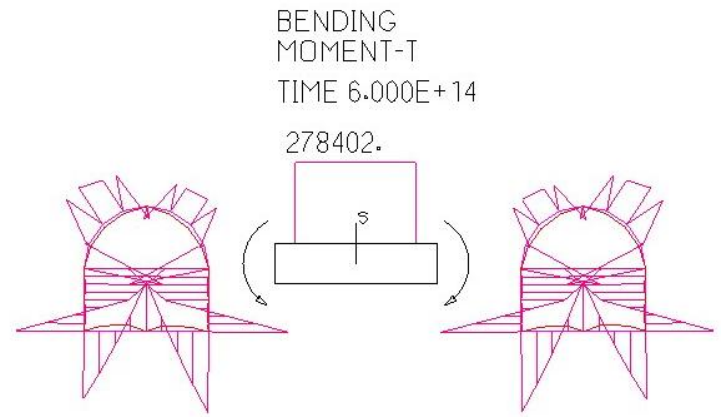

Fig (21): maximum BM of Horse shoe tunnel $(E s, \mu)=(500,0.39), t / r=0.5$, case 1

Table 3: Values of max BM $\left(\operatorname{ton} / \mathrm{m}^{2}\right)$ for circular tunnel at $\mathrm{t} / \mathrm{r}=\mathbf{0 . 5}$.

\begin{tabular}{|c|c|c|c|}
\hline$(\mathbf{E s}, \boldsymbol{\mu})$ & Case 1 & Case 2 & Cas3 \\
\hline $\mathbf{( 5 0 0 , 0 . 3 9 )}$ & 79.364 & 96.104 & 89.06 \\
\hline$(\mathbf{1 0 0 0 , 0 . 4 5})$ & 80.746 & 99.086 & 91.18 \\
\hline$(\mathbf{1 5 0 0 , 0 . 4 9})$ & 108.565 & 129.591 & 112.33 \\
\hline
\end{tabular}


Table 4 :Values of $\max B M(\operatorname{ton} / \mathrm{m} 2)$ for elliptical tunnel at $\mathrm{t} / \mathbf{r}=0.5$.

\begin{tabular}{|c|c|c|c|}
\hline$(\mathrm{Es}, \mu)$ & Case 1 & Case 2 & Cas3 \\
\hline$(500,0.39)$ & ros,roo & YYq,OVY & IVA,YTY \\
\hline$(1000,0.45)$ & YTY,VI & 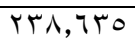 & IAN,OYT \\
\hline$(1500,0.49)$ & YTY,qY & $r \varepsilon \cdot, r \cdot r$ & $194, V \vee 9$ \\
\hline
\end{tabular}

Table $\bullet$ Values of max BM (ton /m2) for Horse shoe tunnel at $\mathbf{t} / \mathbf{r}=0.5$.

\begin{tabular}{|c|c|c|c|}
\hline$(\mathrm{Es}, \mu)$ & Case 1 & Case 2 & Cas3 \\
\hline$(500,0.39)$ & rVA, $\varepsilon \cdot r$ & YqV,0 & rON,NT \\
\hline$(1000,0.45)$ & rVq, I. & rqA,TrY & roq,7rV \\
\hline$(1500,0.49)$ & 328.451 & $r \leqslant T, 0 Y T$ & TVT,.TY \\
\hline
\end{tabular}

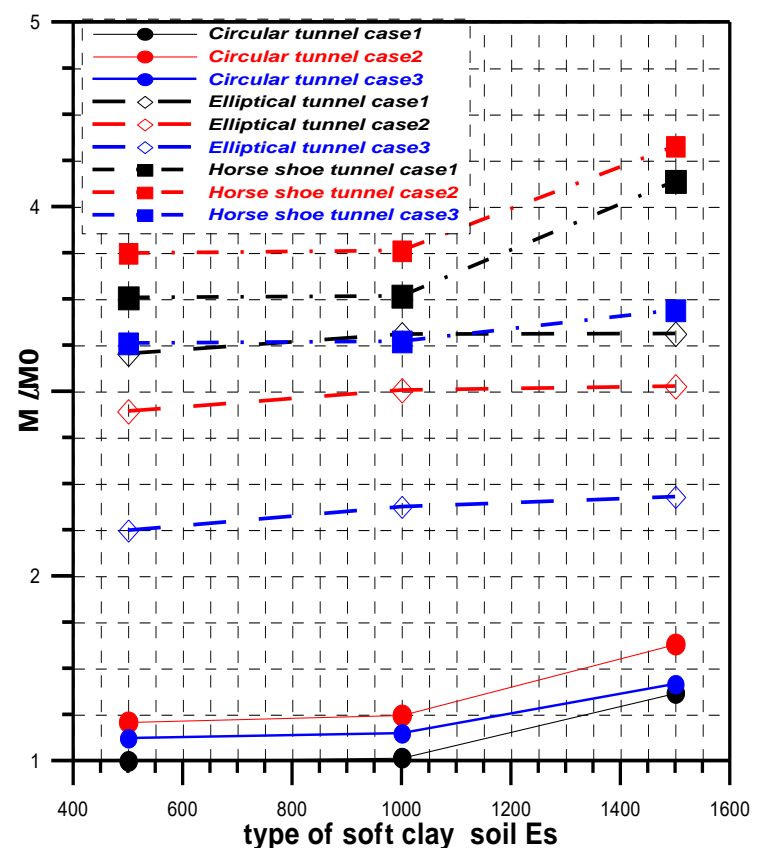

Fig (22): Effect of type of soft clay soil on the Bending moment BM, $\mathrm{t} / \mathrm{r}=0.5$

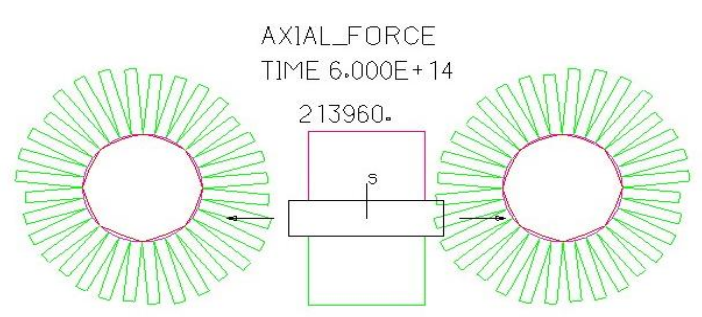

Fig (23): maximum NF of circular tunnel $(E s, \mu)=(500,0.39), t / r=0.5$, case 1

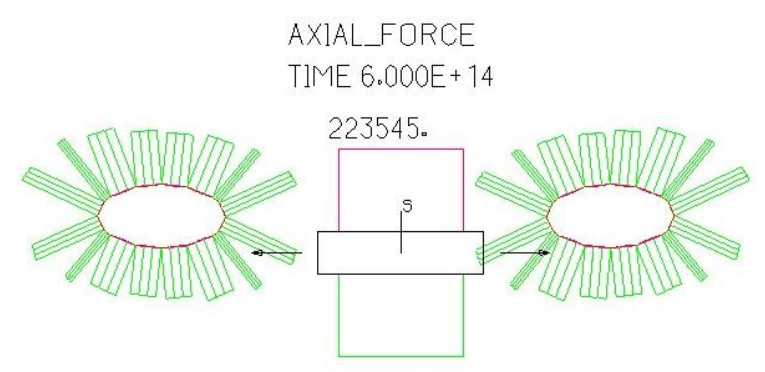

Fig (24): maximum NF of Elliptical tunnel $($ Es, $\mu)=(500,0.39), t / r=0.5$, case 1

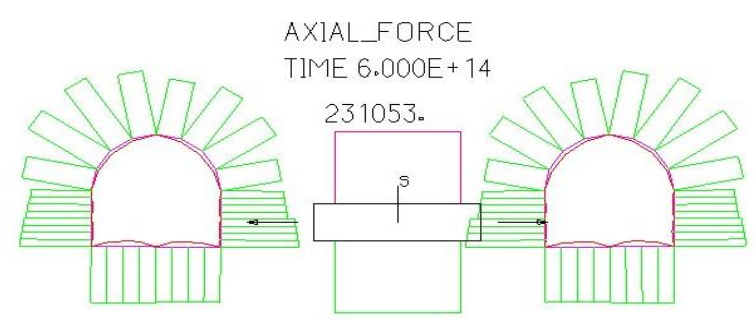

Fig (25): maximum NF of Horse shoe tunnel $(\mathrm{Es}, \boldsymbol{\mu})=(\mathbf{5 0 0 , 0 . 3 9}), \mathrm{t} / \mathrm{r}=0.5, \mathrm{case} 1$.

Table 6 Values of max NF (ton) for circular tunnel at $\mathrm{t} / \mathbf{r}=\mathbf{0 . 5}$.

\begin{tabular}{|c|c|c|c|}
\hline$($ Es, $\boldsymbol{\mu})$ & Case 1 & Case 2 & Cas3 \\
\hline$(\mathbf{5 0 0 , 0 . 3 9 )}$ & 213.96 & 217.211 & 185.74 \\
\hline$(\mathbf{1 0 0 0 , 0 . 4 5})$ & 218.25 & 221.246 & 185.88 \\
\hline$(\mathbf{1 5 0 0 , 0 . 4 9 )}$ & 206.102 & 213.39 & 177.49 \\
\hline
\end{tabular}

Table 7 Values of max NF (ton) for elliptical tunnel at $\mathrm{t} / \mathrm{r}=0.5$.

\begin{tabular}{|c|c|c|c|}
\hline$(\mathbf{E s}, \boldsymbol{\mu})$ & Case 1 & Case 2 & Cas3 \\
\hline$(\mathbf{5 0 0 , 0 . 3 9})$ & 233.45 & 218.191 & 176.04 \\
\hline$(\mathbf{1 0 0 0 , 0 . 4 5 )}$ & 221.73 & 218.181 & 177.622 \\
\hline$(\mathbf{1 5 0 0 , 0 . 4 9 )}$ & 220.780 & 218.132 & 184.13 \\
\hline
\end{tabular}

Table 8 Values of max NF (ton) for Horse shoe tunnel at $\mathbf{t} / \mathbf{r}=0.5$.

\begin{tabular}{|c|c|c|c|}
\hline$(\mathbf{E s}, \boldsymbol{\mu})$ & Case 1 & Case 2 & Cas3 \\
\hline$(\mathbf{5 0 0 , 0 . 3 9 )}$ & 231.053 & 231.59 & 188.285 \\
\hline$(\mathbf{1 0 0 0 , 0 . 4 5 )}$ & 240.908 & 241.714 & 197.336 \\
\hline$(\mathbf{1 5 0 0 , 0 . 4 9 )}$ & $r 63.786$ & 263.901 & 217.259 \\
\hline
\end{tabular}




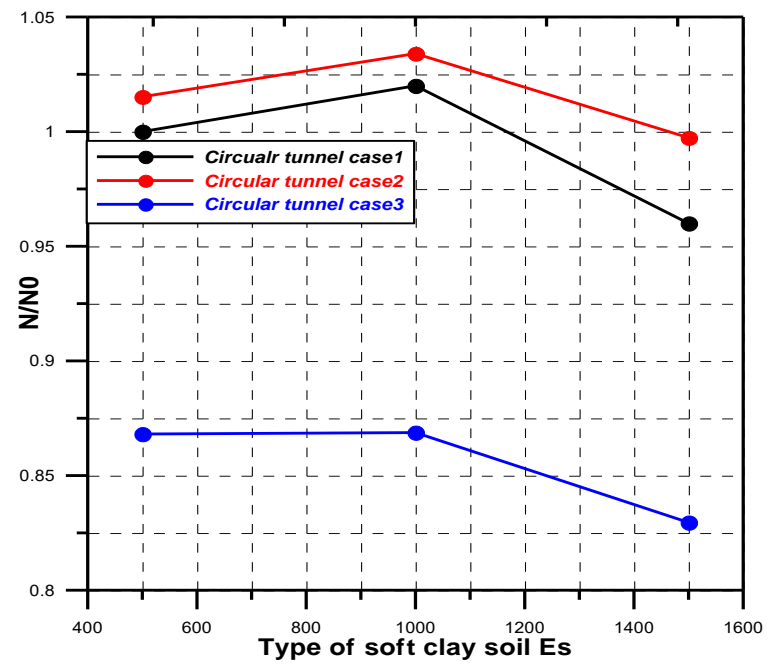

Fig (26): Effect of type of soft clay soil Es on the Circular tunnel Normal force $\mathrm{NF}, \mathrm{t} / \mathrm{r}=\mathbf{0 . 5}$.

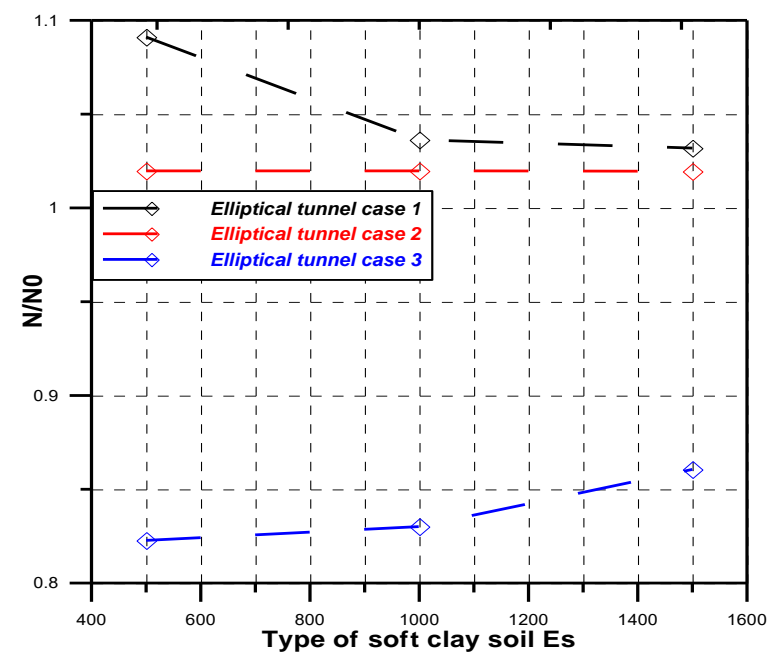

Fig (27): Effect of type of soft clay soil Es on the Elliptical tunnel Normal force NF, $t / r=0.5$.

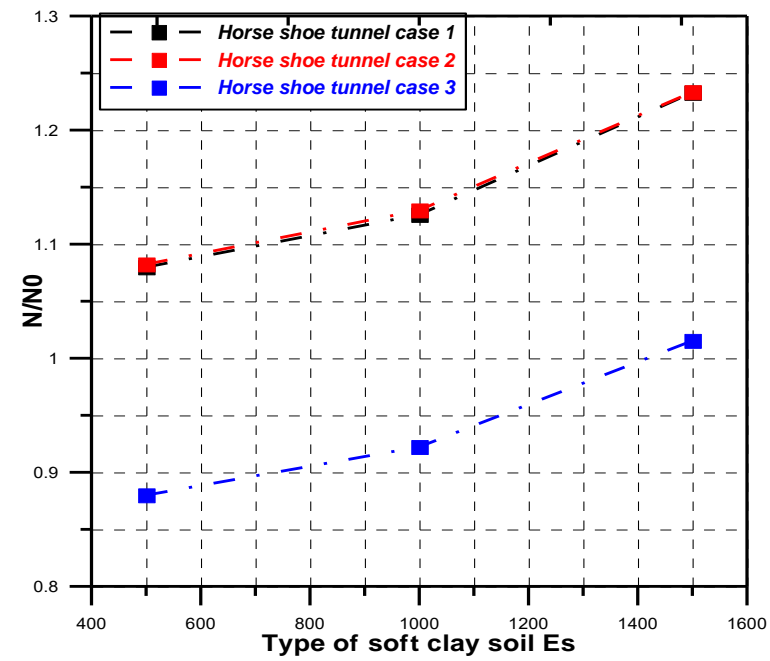

Fig (28): Effect of type of soft clay soil on the Horse shoe tunnel Normal force NF, $t / r=0.5$.
From above tables it is noticed that the BM for circular, elliptical and horse shoe tunnel are increase as increase of (Es, $\mu)$ and after Comparisons between the values of BM and $\mathrm{NF}$ for all shapes it is observed the circular tunnel is less than the elliptical tunnel and the elliptical tunnel less than the horse shoe tunnel. (Fig $2 r$ ) the B.M are affected by case of loading which decrease at case 1 than case 2 circular tunnel and horse shoe tunnel but B.M at Elliptical tunnel increased at case 1 than case 2 .also it is noticed the B.M are affected by the values of an elasticity modulus ,Poisson ratio (Es, $\mu$ ) for soft clay which the BM increased due increased (Es, $\mu$ ). Fig (2 7 , $\left.2^{\vee}, 2 \wedge\right)$ the NF affected by case of loading which decrease at case 1 than case 2 circular tunnel and horse shoe tunnel .but NF at Elliptical tunnel increased at case 1 than case 2 .

\section{INTERNAL STRESSES AND SETELMENT IN SOFT CLAY SOIL}

In this study the effect of each previous parameter on the soil stresses and dis-placements:Fig (29), (30) and (31) show the distribution of settlement on soft clay soil for the three shapes of tunnel an applied pressure of $100 \mathrm{kN} / \mathrm{m}$ ' due change the modulus of elasticity Es $=1900$,

1500 and $1000 \mathrm{kN} / \mathrm{m}^{2}$, the analysis in Adina program is given the max settlement for the different shape as follow table (9), (10) and(11) and after Comparisons between the result, it obtained for all shapes the settlement is increased due decrease the modulus of elasticity Es.

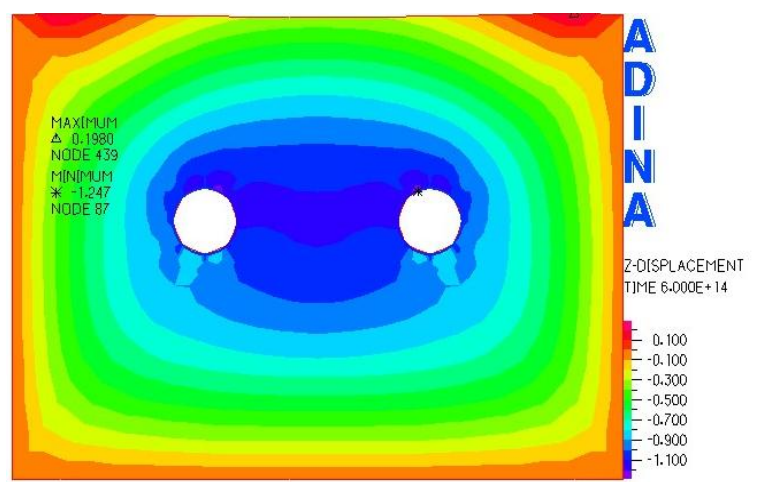

Fig (29): maximum settlement ( $\mathrm{mm}$ ) on soft clay soil (Es, $\mu$ ) $=(500,0.39)$, circular tunnel $t / r=0.5$, case 1 . 


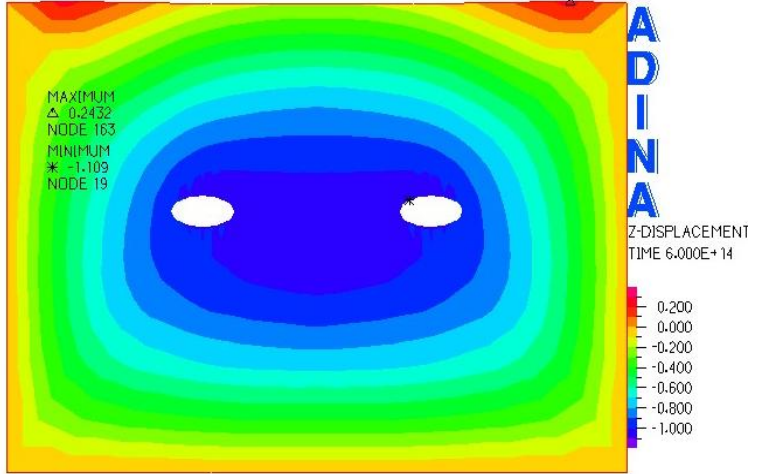

Fig (30): maximum settlement (mm) on soft clay soil (Es, $\mu)$ $=(500,0.39)$, Elliptical tunnel $t / r=0.5$, case 1 .

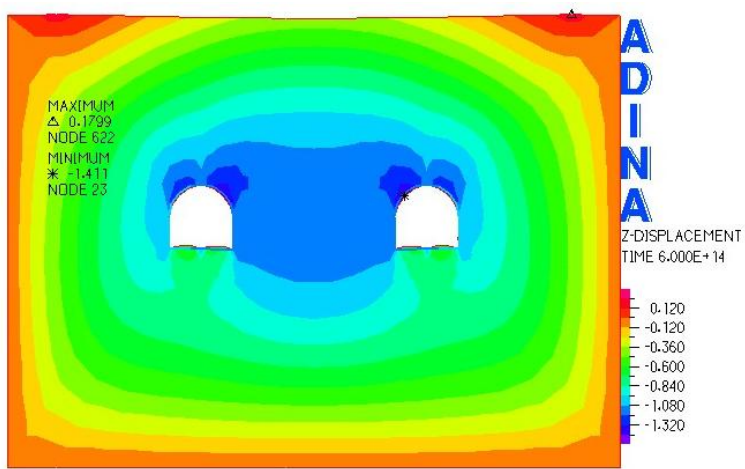

Fig (31): maximum settlement ( $\mathrm{mm})$ on soft clay soil $(\mathrm{Es}, \mu)$ $=(500,0.39)$, Horse shoe tunnel

Table 9: Values of max settlement ( $\mathrm{mm})$ in soft clay soil for circular tunnel at $\mathrm{t} / \mathrm{r}=\mathbf{0 . 5}$.

\begin{tabular}{|c|c|c|l|}
\hline$(\mathbf{E s}, \boldsymbol{\mu})$ & Case 1 & Case 2 & \multicolumn{1}{|c|}{ Cas3 } \\
\hline$(\mathbf{5 0 0 , 0 . 3 9 )}$ & 1247 & 1284 & 1218 \\
\hline$(\mathbf{1 0 0 0 , 0 . 4 5})$ & 391.9 & 406 & 383.3 \\
\hline$(\mathbf{1 5 0 0 , 0 . 4 9 )}$ & 88 & 94 & 86 \\
\hline
\end{tabular}

Table10: Values of max settlement ( $\mathrm{mm}$ ) in soft clay soil for Elliptical tunnel at $\mathrm{t} / \mathrm{r}=0.5$.

\begin{tabular}{|c|c|c|c|}
\hline$($ Es, $\boldsymbol{\mu})$ & Case 1 & Case 2 & \multicolumn{1}{c|}{ Cas3 } \\
\hline$(\mathbf{5 0 0 , 0 . 3 9 )}$ & 11.9 & 1179 & $110 \uparrow$ \\
\hline$(\mathbf{1 0 0 0 , 0 . 4 5 )}$ & $r r r . \varepsilon$ & $r \circ \varepsilon .0$ & $r \varepsilon \wedge . r$ \\
\hline$(\mathbf{1 5 0 0 , 0 . 4 9 )}$ & 73 & $\vee q$ & $\vee 0.0$ \\
\hline
\end{tabular}

Table 11 :Values of max settlement $(\mathrm{mm})$ in soft clay soil for Horse shoe tunnel at $\mathrm{t} / \mathrm{r}=0.5$.

\begin{tabular}{|c|c|c|c|}
\hline$(\mathrm{Es}, \boldsymbol{\mu})$ & Case 1 & Case 2 & Cas3 \\
\hline$(500,0.39)$ & $1 \leqslant 10$ & $1 \leqslant 00$ & $1 T \leq r$ \\
\hline$(1000,0.45)$ & $\leqslant 79$ & $\varepsilon V \varepsilon$ & $\varepsilon r \varepsilon$ \\
\hline$(1500,0.49)$ & 111 & $11 \mathrm{~V}$ & 1.7 \\
\hline
\end{tabular}

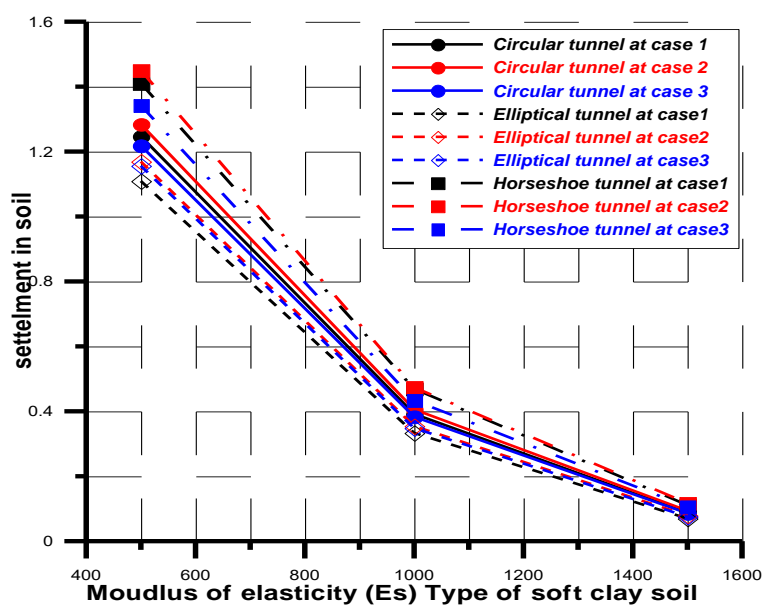

Fig (32): Effect of type of soft clay soil on the settlement in soft clay soil, $t / r=0.5$.

From Fig(32) the settlement in soft clay around the elliptical tunnel is decrease from $6 \%$ to $11 \%$ at (Es, $\mu)=(500,0.39), 10 \%$ to $15 \%$ at $($ Es, $\mu)=$ $(1000,0.45), 12 \%$ to $17 \%$ at $($ Es, $\mu)=(1500,0.49)$ than the circular tunnel.

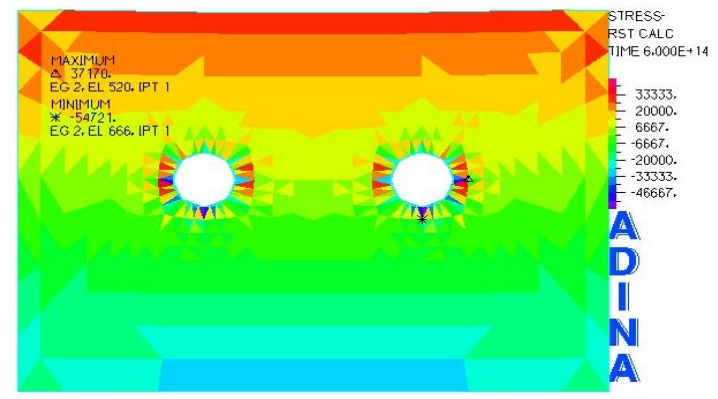

Fig (33): maximum horizontal stress $\sigma x x$ on soft clay soil $(E s, \mu)=(500,0.39)$, circular tunnel.

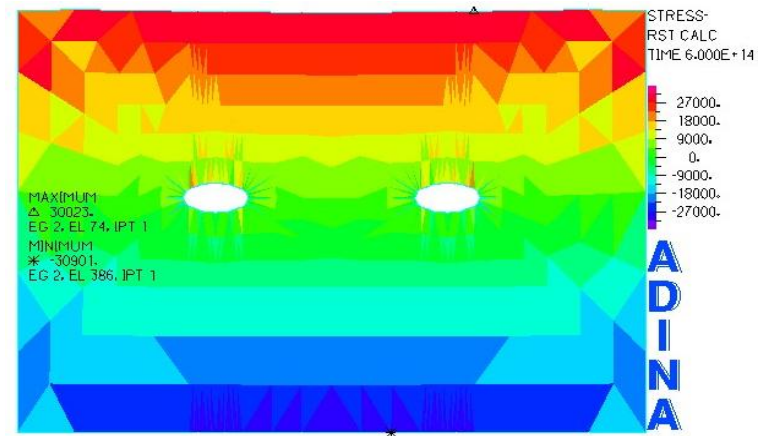

Fig (34): maximum horizontal stress $\sigma x x$ on soft clay soil $($ Es, $\mu)=(500,0.39)$, Elliptical tunnel. 


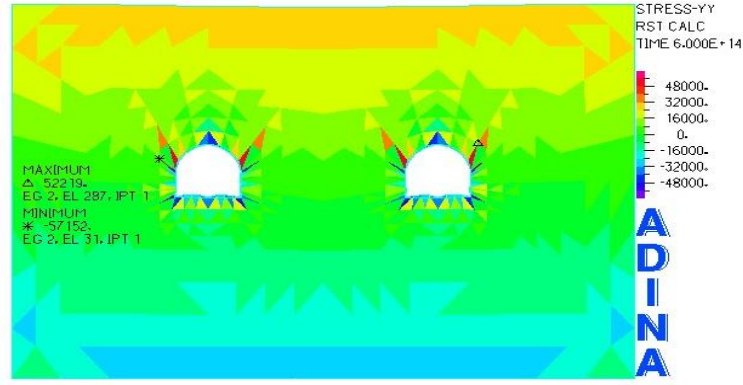

Fig (35): maximum horizontal stress $\sigma x x$ on soft clay soil $(E s, \mu)=(500,0.39)$, Horse shoe tunnel.

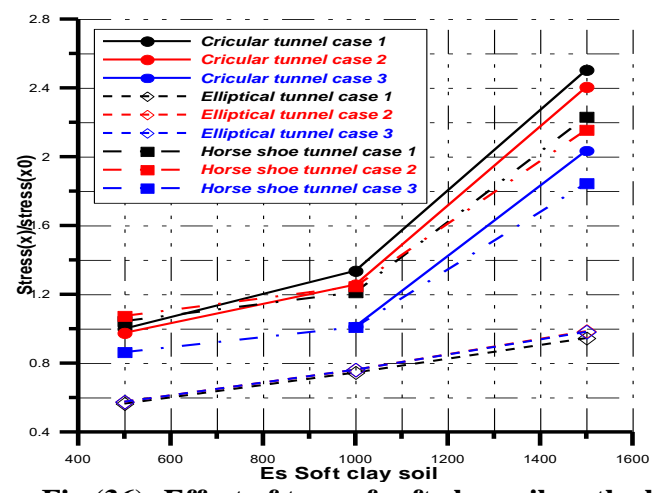

Fig (36): Effect of type of soft clay soil on the horizontal stress $\sigma x x$ in soft clay soil, $t / r=0.5$.

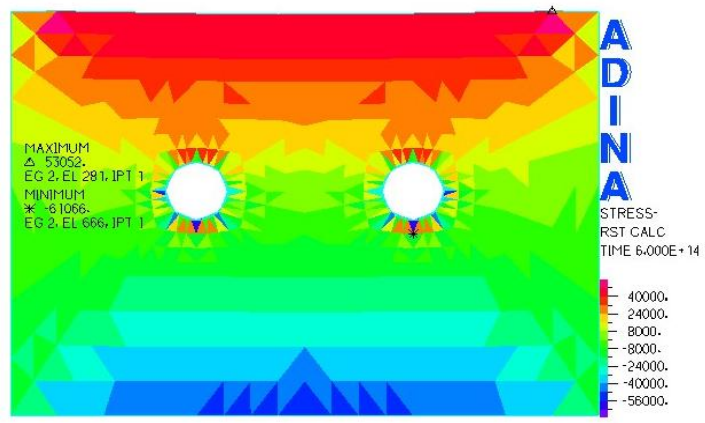

Fig (37): maximum vertical stress $\sigma y y$ on soft clay soil $(E s, \mu)=(500,0.39)$, circular tunnel.

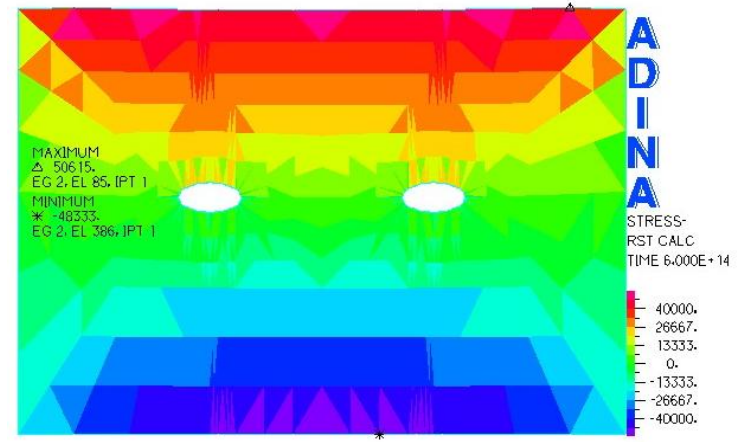

Fig (38): maximum vertical stress $\sigma y y$ on soft clay soil $(E s, \mu)=(500,0.39)$, circular tunnel.

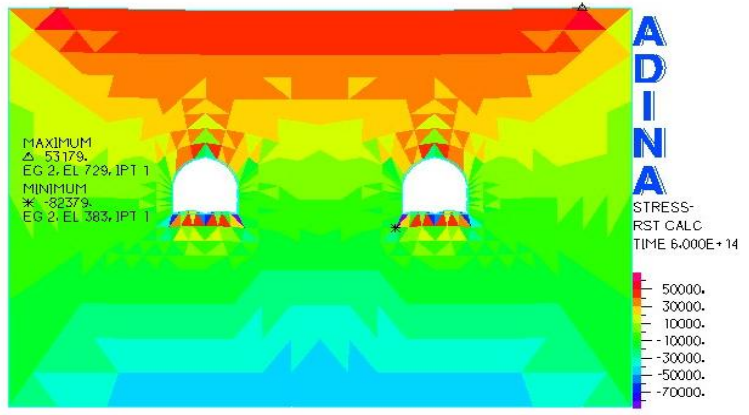

Fig (39): maximum vertical stress $\sigma y y$ on soft clay soil $(\mathrm{Es}, \boldsymbol{\mu})=(\mathbf{5 0 0 , 0 . 3 9})$, circular tunnel.

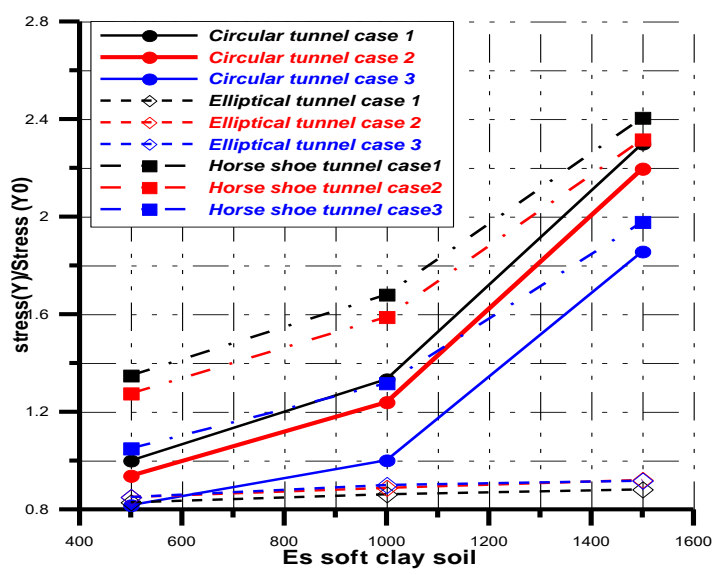

Fig (40): Effect of type of soft clay soil on the vertical stress $\sigma y y$ in soft clay soil, $t / r=0.5$

From above figures the normal stresses $\left(\sigma_{x}, \sigma_{y}\right)$ around the lining of tunnel are affected by the values of an elastic modulus and Poisson ratio type of soft clay soil and shape of tunnel, which the stress around the elliptical tunnel is decrease than the circular and the horse shoe tunnel, the normal stress in soft clay soil is increase due to increase the values of an elastic modulus and Poisson ratio.

\section{CONCLUSIONS}

After many studies for the three shapes of tunnel and after comparisons between the values of displacement at upper (cr), internal forces of lining and internal stress of soft clay soil for circular , elliptical and horse shoe tunnel it is observed :1- In general, the Elliptical tunnel decrease soil settlement, and stresses in soft clay soil but the circular tunnel decrease internal force domain which achieves economic design.

2- The displacement at upper (cr) when an elastic modulus of soil and Poisson ratio change from(Es, $\mu)=(500,0.39)$ to $($ Es, $\mu)=(1000,0.45)$, decrease 
70\%. the displacement at (cr) when an elastic modulus of soil and Poisson ratio change from(Es, $\mu)=(1000,0.45)$ to $($ Es, $\mu)=(1500,0.49)$ decrease $80 \%$

3-.The displacement at upper (cr) of circular tunnel in soft clay soil increase when Es $=500 \mathrm{t} / \mathrm{m} 2$ about $13 \%, \mathrm{Es}=1000 \mathrm{t} / \mathrm{m} 216 \%$ and $\mathrm{Es}=1500 \mathrm{t} / \mathrm{m} 2(25 \%$ to $30 \%$ ) due to change the ratio of $\mathrm{t} / \mathrm{R}$ from 0.1 to 0.5 .

4-The displacement at upper (cr) of Elliptical tunnel in soft clay soil increase when Es $=500 \mathrm{t} / \mathrm{m} 2$ about $10 \%, \mathrm{Es}=1000 \mathrm{t} / \mathrm{m} 211 \%$ and $\mathrm{Es}=1500 \mathrm{t} / \mathrm{m} 2$ about $20 \%$ due to change the ratio of $\mathrm{t} / \mathrm{R}$ from 0.1 to 0.5 .

5- The displacement at upper (cr) of Horse shoe tunnel in soft clay soil increase when Es $=500 \mathrm{t} / \mathrm{m} 2$ about $15 \%, \mathrm{Es}=1000 \mathrm{t} / \mathrm{m} 218 \%$ and $\mathrm{Es}=1500 \mathrm{t} / \mathrm{m} 2$ about $30 \%$ due to change the ratio of $\mathrm{t} / \mathrm{R}$ from 0.1 to 0.5 .

6- The settlement in soft clay the elliptical tunnel is decrease from $6 \%$ to $17 \%$ than the circular tunnel due increase the values of an elastic modulus, Poisson ratio (Es, $\mu$ )

\section{.REFRENCES}

[1] Abdel Razik, M. (1985), "The Analysis of Circular Rings As A Section Elastically Embedded In The Subsoil", M.Sc. Thesis, Structural Engineering Department, Faculty Of Engineering, Al-Azhar University.

[2] Abo elanwar.M. (2006) "Analysis Of Circular Tunnels Embedded In Soil ", M.Sc. Thesis, Civil Engineering Department, Faculty Of Engineering, Al-Azhar University

[3] . Ahmed, A.(1991)"Interaction of Tunnel Lining and Ground" Ph. D. Thesis, Dept. of Civil eng, Ain Shams University, Cairo, Egypt

[4] Akl, M.Y. ( 1989 ), “ Analysis Of Segmental Tunnles ”, M.Sc. Thesis, Civil Engineering Department, Faculty Of Engineering, Cairo University.

[5] Attia, G. (1991), “ Numerical And Photoelastic Analyses Of Tunnels Containing Cracks ", Ph.D. Thesis, Structural Engineering Department, Faculty Of Engineering, Zagazig University
[6] Attia, G. , El-Shamy, E. , and others. (2000), “ Experimental Analysis Of Two Adjacent Cracked Tunnels " Proc. Of The Eighth Structural Engineering Conference, Zagazig University.

[7] Bakker, K.J., Bore, F., Admiraal, J.B.M., Leendertse, W.L., Jovanovic, P.S. and van Oosterhout, G.P.C. ( 2001 ), " Monitoring Two Tunnels ”, Feature Article, Civil Engineering ASCE, Vol. 71, No. 2, PP. A10-A16.

[8] Bowles, Joseph E. (1986), "Foundation Analysis And Design" Second Edition, Mcgraw-Hill. Inc.

[9] Chong Hun YEO, Fook Hou LEE, See Chee TAN, Osamu HASEGAWA, Hitoshi SUZUKI, Masato SHINJI (2008) "Three Dimensional Numerical Modeling of A NATM Tunnel The Design Of NATM Tunnels Are Often Done In Two Dimensions.

[10] C. Leung, M.A. Meguid (2010)" An Experimental Study of The Effect Of Local Contact Loss On The Earth Pressure Distribution On Existing Tunnel Linings"

[11] El Gammal, M.H.A. ( 1981 ), “ Stress Distribution Around Two Unequal Circular Tunnels ", M.Sc. Thesis, Civil Engineering Department, Faculty of Engineering, Cairo University.

[12] El Tahawy, Y.B. ( 1975 ), “ Stress Distrebution Around Circular And Rectangular Adjecent Underground ", M.Sc. Thesis, Civil Engineering Department, Faculty Of Engineering, Cairo University.

[13] El-Shihy, A.M., Abd El-Salam, S.S and ElAassar H.M. .(1991) "Finite Element Analysis of open R.C. Tunnels" Proceeding of International Symposium on Tunnelling in Congested Cities, Tanuary 28-29, ,Cairo, Egypt, PP. 301-319 
ANALYSIS OF TWO ADJACENT TUNNELS IN SOFT CLAY SOIL

Attia, Elshamey, Fawzy, Abdul-hafez

[14] El-Nahhas, M.F., El-Kadi, F. and Shalaby, .(1990) A "Tunnel and under Ground Works Today and Future" Proceeding of the International Congress, sept, 3-7,. Cheng $d u$, China, V, (1) PP. 375-382.

[15] Eman.A.Elshamy."Numerical and Experimental analysis of cracked two adjacent tunnels"Ph.D Theies, Zagazig University 1997.

[16] Finite Element Adina Computer Program Version 8.5

[17] Gouda A. Mohamed, Eman A. El-Shamy, Adel Y. Akle and Sayed Abdel Salam "Experimental Analysis of Two Adjacent Cracked Tunnels" 8th Arab Structural Engineering conference, Cairo, October 21-23, 2000

[18] Hefny, A.M., Tan, F.C., and Macalevey, N.F. ( 2004 ), " Numerical Study on the Behavior of Jointed Tunnel Lining " , J. Of Institution Of Engineering, Singapore, Vol. 44, Issue 1, 2004, PP. 108 - 118.

[19] Kentaro Yamamoto , Andrei V. Lyamin, Daniel W. Wilson, Scott W. Sloan, Andrew J. Abbo (2011) "Stability Of A circular Tunnel In Cohesive-Frictional Soil Subjected To Surcharge Loading"

[20] LEE, C. J., WU, B.R., and CHIOU, S.Y., ( 1999 ), " Soil Movements Around a Tunnel in Soft Soils”, Proc. Nztl. Sci. Counc. ROC(A), Vol. 23, No. 2, PP. $235-247$

[21] M. Alba, L. Barazzetti, A. Giussani, F. Roncoroni, M. Scaioni (2010) "Development And Testing Of A method For Tunnel Monitoring Via Vision Metrology”.

[22] Mahdy, I.M. (1990) "Tunnel Construction in Egypt" M. Sc. Thesis, construction Dept., Zagazig University,

[23] Saied Mohammad Farouq Hossaini, Mehri Shaban and Alireza Talebinejad (2012) " Relationship Between Twin Tunnel Distance And Surface Subsidence In Soft Ground" 